\title{
Rynek kryptowalut - sytuacja bieżąca i kierunki rozwoju
}

\begin{abstract}
Cryptocurrency market: current situation and future development: The article provides a general overview of blockchain technology and its influence on cryptocurrency development. It is based on asymmetric cryptology, peer-to-peer technology, hash functions, consensus mechanism, and smart contracts. Since 2008, when Satoshi Nakamoto published online the Bitcoin blueprint, cryptocurrency market has grown. There are more than 1000 cryptocurrencies now (e.g. Ethereum, Dogecoin, Monero), as well as many stock exchange markets, exchange offices and bitcoin cash machines. It is also possible to "mine" cryptocurrencies by yourself, however special hardware solutions are required. The author claims that cryptocurrency has redefined the way of thinking and viewing the concept of money, and it will expand even further.
\end{abstract}
Słowa kluczowe: $\quad$ waluta wirtualna, bitcoin, blockchain, „wydobywanie walut”, rynek walut wirtualnych
Keywords: cryptocurrency, Bitcoin, blockchain, „currency mining”, cryptocur- rency market

* Doktor nauk ekonomicznych, Uczelnia Techniczno-Handlowa im. Heleny Chodkowskiejw Warszawie; e-mail: agnieszka.wikarczyk@uth.edu.pl.

\section{Wstęp}

„Bitcoin” jest jednym z najlepiej rozpoznawalnych terminów z obszaru finansów. Fenomen rosnącej od 2008 r. popularności tej waluty wynikał m.in. z sytuacji gospodarczej. Na świecie trwał wówczas kryzys finansowy (2007-2009). Zaufanie wielu osób do instytucji finansowych drastycznie spadło. Odpowiedzią na to zjawisko, ale i na potrzebę znalezienia nowej, bezpiecznej drogi komunikacji między systemami informatycznymi, stał się projekt systemu Bitcoin oparty na technologii łańcucha bloków (blockchain). 3 stycznia 2009 r. została wydana pierwsza wersja oprogramowania do obsługi portfela bitcoinowego. Przełomowa okazała się nie tylko koncepcja waluty cyfrowej, ale i wskazana technologia. W artykule zostanie przedstawiony rynek kryptowalut (zasady i sposoby obrotu 
kryptowalutami) oraz perspektywy jego rozwoju (na bazie zalet i wad kryptowalut). Autorka stawia tezę, że stworzenie bitcoina (i kolejnych kryptowalut) jest próbą znalezienia substytutu tradycyjnego pieniądza (spełniającego funkcję środka wymiany $\mathrm{i}$ instrumentu inwestycyjnego).

\section{Kryptowaluta - definicja i istota}

W dniu 31 października 2008 r. nieznana osoba (lub osoby), przedstawiając się jako Satoshi Nakamoto, wprowadziła koncepcję bitcoina (pierwszej waluty wirtualnej, nazwanej później kryptowalutą ${ }^{1}$ ), udostępniając publikację Bitcoin: system elektronicznej gotówki peer-to-peer ${ }^{2}$. Odniesiono się w niej do problemów związanych z prowadzeniem komercyjnych transakcji przez internet, które opierają się praktycznie na instytucjach finansowych (przy niewielkim udziale w rynku innych rodzajów podmiotów), pełniących rolę zaufanych jednostek, przetwarzających elektroniczne płatności przy wykorzystaniu pieniądza tradycyjnego (głównie bezgotówkowego). Podczas dokonywania tych płatności instytucje te mogą sprawdzić każdą transakcję, aby zapobiec m.in. podwójnemu przelewaniu tych samych środków, a więc sytuacjom, gdy nieuczciwy nabywca próbuje dwukrotnie wydać te same pieniądze. Jednak system tak skonstruowany musi opierać się na zaufaniu do określonej instytucji. Alternatywą okazało się opracowanie elektronicznego systemu płatności, ale bazującego na dowodzie kryptograficznym, a nie na zaufaniu, pozwalając dwóm zainteresowanym stronom wykonywać transakcje bezpośrednio ze sobą (czyli P2P), bez konieczności współpracy z dodatkowymi instytucjami. Autor publikacji sugerował użycie powiązanych ze sobą koncepcji bitcoina (waluty) i tzw. łańcucha bloków (ang. blockchain ${ }^{3}$ ) jako sposobu na realizację takiego rozwiązania ${ }^{4}$.

Łańcuch bloków jest to technologia porównywana do wynalazku, jakim jest internet. Jest to „wielka księga transakcyjna”, która nie ma jednego właściciela, a dostęp do niej może mieć każdy (pozwala przechowywać i wymieniać infor-

1 „Kryptowaluta” jest kojarzona ze znaczeniem przedrostka „krypto-” („coś ukrytego”). Pochodzi od: „kryptologii”, czyli dziedziny wiedzy o przekazywaniu informacji w sposób zabezpieczony przed niepowołanym dostępem; Podstawy korzystania $z$ walut cyfrowych, red. K. Piech, Instytut Wiedzy i Innowacji, Warszawa 2017, s. 9.

2 Bitcoin: A peer-to-peer electronic cash system, s. 6, www.bitcoin.org/bitcoin.pdf [dostęp: 5 grudnia 2018 r.]; B. Klinger, J. Szczepański, Blockchain - historia, cechy i główne obszary zastosowań, „Człowiek w Cyperprzestrzeni” 2017, nr 1, s. 12. Peer-to-peer (dalej: P2P) to inaczej sieć równorzędna typu „każdy z każdym”, https://poradnikprzedsiebiorcy.pl/-peer-to-peer-definicja-historia-powstania-i-wplyw-na-rozwoj-internetu-cz-1 [dostęp: 9 grudnia 2018 r.].

3 W literaturze przyjęło się stosować nazwę angielską. Łańcuch bloków jest oparty na połączeniu: technologii P2P i szyfrowania asymetrycznego (wykorzystującego tzw. klucz publiczny i prywatny); Podstawy korzystania, op. cit., s. 16; R. Pietras, Jak działa Bitcoin, "Chip" z 12 marca 2018 r.

${ }^{4}$ Https://pl.farnell.com/cryptocurrency-ecosystem [dostęp: 11 grudnia 2018 r.]. 
macje na bazie architektury sieci $\mathrm{P}^{2} \mathrm{P}^{5}$ ). Jest całkowicie transparentna, a raz zapisane i zatwierdzone przez uczestników sieci zmiany są trudne do zastąpienia (wymagają zmian wszystkich powiązanych bloków). W tym znaczeniu jest uważana za odporną na przejęcie kontroli przez jedną osobę oraz fałszerstwa, ponieważ używana jest w niej funkcja kryptograficzna. Łańcuch bloków bazuje także na innych, znanych technologiach używanych już masowo, czyli:

- funkcji skrótu (tzw. haszującej ${ }^{6}$ - za jej pomocą można wyliczyć „skrót” rozbudowanych danych (jest używany w łańcuchu bloków - transakcje są zapisywane skrótami oddzielnie, a cały zestaw transakcji „zapakowany” w dany blok jest odwzorowany za pomocą drzewa skrótów),

- $\quad$ szyfrowaniu asymetrycznym ${ }^{7}$ - wykorzystuje się klucz publiczny i prywatny; klucza prywatnego nie da się łatwo odtworzyć na podstawie publicznego; ten pierwszy można przygotować samemu albo skorzystać z gotowej aplikacji, która używa algorytmu jednokierunkowego, takiego jak funkcja skrótu (tworzy na podstawie klucza prywatnego klucz publiczny służący do zweryfikowania tożsamości, np. przez bank),

- znakowaniu czasem - czas w sieci blockchain jest synchronizowany między uczestnikami sieci (węzłami): [...] Dzięki temu wszystkie obiekty i zdarzenia w blockchain sq bardzo precyzyjnie umieszczone na zsynchronizowanej osi czasu i razem tworza wiarygodna, ułożona chronologicznie historię $e^{8}$,

- proof of work, czyli na „dowodzie pracy”" - jest to implementacja tzw. konsensusu Nakamoto, polegającego na przeprowadzeniu dla każdego nowego bloku pewnego rodzaju loterii i wyborze węzła-lidera, który będzie mógł zaproponować nowy blok przeznaczony do dołączenia do łańcucha, a po zatwierdzeniu tego bloku przez inne węzły uzyskać wynagrodzenie za dodanie tego bloku ${ }^{10}$ (to zachęta ekonomiczna zastosowana w systemie bitcoin - w taki m.in. sposób pozyskują go uczestnicy rynku),

5 Blockchain, a catalyst for new approaches in insurance, PWC, s. 6, https://www.pwc.com/ gx/en/insurance/assets/blockchain-a-catalyst.pdf [dostęp: 10 grudnia 2018 r.]

${ }^{6}$ Ang. hash - skrót. Jest: odporny na tzw. kolizje - dwa różne zestawy danych nie dadzq tego samego skrótu i nie ma praktycznej możliwości wygenerowania zestawu danych o takim samym skrócie jak wskazany zestaw danych, jednokierunkowy, nieodwracalny - nie da sie odtworzyć oryginalnej wiadomości znajac jej skrót, B. Klinger, J. Szczepański, Blockchain historia, op. cit., s. 14; R. Pietras, Jak działa Bitcoin, op. cit.

7 Asymetryczny algorytm szyfrowania musi mieć jeszcze jedną własność: symetrię pomiędzy kluczami - informacje zaszyfrowane kluczem publicznym można odszyfrować tylko prywatnym, ale zaszyfrowane kluczem prywatnym muszą się dać odszyfrować kluczem publicznym. Podstawy korzystania, op. cit., s. 16; https://pl.farnell.com/cryptocurrency-ecosystem [dostęp: 11 grudnia 2018 r.]; R. Pietras, Jak działa Bitcoin, op. cit.

8 B. Klinger, J. Szczepański, Blockchain - historia, op. cit., s. 16.

9 Podstawy korzystania, op. cit., s. 10; D. Homa, Sekrety Bitcoina i innych kryptowalut, Helion, Gliwice 2015, s. 32-37.

${ }_{10}$ Podstawy korzystania, op. cit., s. 16-17. 
- inteligentnych kontraktach (smart contracts) - są to wyspecjalizowane programy, które odpowiadają za wykonywanie podczas przetwarzania transakcji dodatkowych operacji zapisanych w ich kodzie programistycznym; sieć uzyskuje dodatkowe możliwości funkcjonalne, pozwalające m.in. definiować nowe, nieznane wcześniej kryptowaluty o praktycznie dowolnych funkcjonalnościach.

Pomijając kwestie programistyczne i matematyczne, blockchain to księga rozrachunkowa zawierająca listę transakcji dokonywanych w danej kryptowalucie (gdy jest przewidziana), a także jednocześnie system transakcyjny. Sama kryptowaluta jest definiowana jako waluta kryptograficzna bądź cyfrowa (umowna jednostka), znajdująca się w tym rozproszonym systemie księgowym, przechowującym informacje o stanie jej posiadania przez uczestników sieci (uważa się go za innowacyjny np. w obszarze sposobu tworzenia i przechowywania pieniędzy $)^{11}$.

Jedną z głównych cech kryptowaluty jest to, że działa jak wirtualna waluta. Jej posiadacz przechowuje ją na swoim komputerze czy w smartfonowej aplikacji w tzw. portfelu, do którego dostęp ma tylko on (w celu szyfrowania danych używa się ogólnodostępnego klucza publicznego, a klucz prywatny, za którego pomocą będzie możliwe odszyfrowanie dokumentu, posiada adresat jednoznacznie weryfikuje osoby). Jeżeli chce dokonać transakcji, to robi to elektronicznie. Transakcja odbywa się bezpośrednio między nim a kontrahentem. Każda jednostka kryptowaluty ma unikalny kod, w którym zawarte są informacje zapobiegające jej kopiowaniu czy ponownemu wydatkowaniu (system jest zabezpieczany przez mechanizm konsensusu i nieustannie prowadzoną przez węzły weryfikację zapisów; ma to przeciwdziałać oszustwom, manipulacjom na danych transakcji ${ }^{12}$, ale nie problemom technicznym). Systemy kryptowalut wykorzystują technologię łańcucha bloków, tworzą zatem niezmienne, znakowane czasem wpisy w rozproszonej bazie danych dla każdej wykonanej, pojedynczej transakcji. Każda transakcja i odpowiadający jej rekord danych są łatwo i jednoznacznie identyfikowalne. Ta baza danych nie ma wyróżnionego węzła centralnego ani żadnego „superadministratora”, dzięki czemu blockchain nie ma pojedynczego punktu awarii. Taka technologia nie jest możliwa jeszcze - przy współczesnym stanie techniki - do łatwego rozszyfrowania i złamania. Przy dobrze zaprojektowanym ( $t$. odpowiednio rozproszonym) blockchainie nie powinno być to możliwe. Dowodem na to jest fakt, że Bitcoin działa [...] nieprzerwanie od ponad 9 lat. Przez blockchain Bitcoinowy przeszły już transakcje o wartości setek miliardów dolarów. [Pisano o tym, że] ani ułamek $z$ nich nie został sfat-

\footnotetext{
11 Ibidem, s. 15.

12 B. Klinger, J. Szczepański, Blockchain - historia, op. cit., s. 18.
} 
szowany, ani utracony ${ }^{13}$, co nie jest prawdą. Należy tu przywołać przypadek giełdy bitomat.pl w 2011 r. czy Mt.Gox w 2014 r. Szacuje się, że ponad 30000 osób padło ofiarą cyberprzestępczości związanej z Ethereum, tracąc średnio 7 500 dolarów US każda, a ponad połowa z tej wielkości (16 900) straciła swoje pieniądze w wyniku phishingu, czyli metody oszustwa, polegającej na tym, że przestępca podszywa się pod inną osobę lub instytucję, w celu wyłudzenia określonych informacji ${ }^{14}$. Ponadto systemy IT i księgowe nie są doskonałe, przez co zdarzają się sytuacje, gdy stan środków się nie zgadza. Określoną pewność, co do stanu wzajemnych rozliczeń, ma przynieść zaangażowana w ich potwierdzanie „strona trzecia”, czyli inni „górnicy” (jak określa się niektórych uczestników strony podażowej).

Kluczowe dla koncepcji kryptowalut jest jednak to, że dostęp nie jest ograniczony geograficznie, a w obrocie nimi nie wskazano żadnego nadzorcy (człowieka/instytucji). Nie ma więc centralnego banku kryptowaluty (jak w przypadku tradycyjnych walut), który może decydować np. o zwiększeniu podaży kryptowaluty i przez to doprowadzić do spadku jej wartości. Jednak w przypadku popularnych kryptowalut (m.in. bitcoina) powstały już podmioty, które np. odtajniają transakcje zawarte w łańcuchu dostaw.

Pasjonaci kryptowaluty pisali, że jej misja sprowadza się do jednego słowa: „wolność", ponieważ jest to waluta elektroniczna, mająca być „całkowicie wolna” od kontroli polityków, organów skarbowych (tak było na początku funkcjonowania kryptowalut), krajowych czy międzynarodowych instytucji finansowych. Obrót nią nie powinien być w żaden sposób kontrolowany, a podlegać jedynie silnemu systemowi elektronicznych, zautomatyzowanych zabezpieczen ${ }^{15}$ (np. zcash jest objęta całkowitą anonimowością, co stanowi jej przewagę nad bitcoinem). Stąd koncepcja kryptowaluty, w tym bitcoina (jako pierwszej kryptowaluty), i łańcucha bloków (niejako kręgosłupa systemu) są ze sobą powiązane i nie powinno się rozpatrywać tych pojęć oddzielnie. Natomiast o tym, ile danej kryptowaluty znajdzie się w obiegu, powinien decydować jej twórca na etapie tworzenia systemu, więc jej wartość teoretycznie znajduje się „w rękach wolnego rynku", czyli uczestników obrotu. Przy tym np. bitcoin stał się już legalnym

1328 lipca 2011 r. doszło do awarii serwera giełdy elektronicznej bitomat.pl. „Zniknęło” wówczas 17 tys. BTC należących głównie do polskich klientów, a tokijska giełda elektroniczna Mt.Gox przejęła polską „giełdę” i zrekompensowała straty właścicielom, https://gieldykryptowalut.pl/wiadomosci/krotka-historia-upadlych-polskich-gield-kryptowalut/ [dostęp: 14 grudnia 2018 r.]; Podstawy korzystania, op. cit., s. 20.

14 Wynika to $\mathrm{z}$ badań przeprowadzonych przez Chainalysis (dostawcę oprogramowania zapobiegającego praniu pieniędzy). Wskazywano w nich również, że: 11000 z poszkodowanych padło ofiara programów mających na celu wykorzystanie błędów w oprogramowaniu, 2100 poniosło stratę z powodu włamania hakera, a jedynie 260 osób straciło swoje środki w zwiazku z piramidami finansowymi, Podstawy korzystania, op. cit., s. 58.

${ }^{15} \mathrm{Https} / /$ ergokantor.pl/co-to-sa-kryptowaluty.html [dostęp: 12 grudnia 2018 r.]. 
środkiem przechowywania wartości i metodą płatności (są to typowe funkcje tradycyjnego pieniądza), na co wskazywał w 2017 r. m.in. Europol ${ }^{16}$.

\section{Kryptowaluty - tworzenie i pozyskiwanie}

Od momentu powstania idei bitcoina (BTC), czyli od 2008 r., pojawiło się ok. tysiąca kryptowalut (w tym m.in. bitcoin cash, ethereum, zcash, monero). Ich działanie oparte jest na idei łańcucha bloków, a po raz pierwszy taki łańcuch powstał 3 stycznia 2009 r. (o nazwie „Genesis”). „Śledzi” wszystkie transakcje w BTC i nieustannie się powiększa: średnio co 10 minut jest dołączany do niego nowy blok (algorytm rozdziela 12,5 BTC pomiędzy wszystkie osoby zaangażowane w ich „wykopywanie” ${ }^{17}$ ), w którym zapisane są transakcje z maksymalnie ostatniej godziny. Blok ma wielkość np. $1 \mathrm{MB}$ dla bitcoina, a jego następca bitcoin cash (BCH), który pojawił się 1 sierpnia 2017 r., ustanowił limit nowego bloku na poziomie $8 \mathrm{MB}$, co znacznie poprawiło szybkość zawieranych transakcji ${ }^{18}$. Panuje przekonanie, że zwiększanie rozmiaru bloków jest konieczne, aby obsłużyć rosnącą liczbę transakcji pojawiających się w sieci (w przeciwnym wypadku sieć stopniowo będzie zwalniać).

Ethereum (ETH) został stworzony w 2013 r. przez Vitalika Buterina ${ }^{19}$ jako nowa, niezależna od bitcoina sieć łańcucha bloków (data ogłoszenia: 23 stycznia 2014 r.). Główna rewolucją funkcjonalna w Ethereum była możliwość „programowania" w blockchain, czyli możliwość użycia [...] wspomnianych wcześniej „inteligentnych kontraktów”), wykonujacych praktycznie dowolne obliczenia, czy przechowujących dane, które po dołączeniu do blockchain pozostawaly niezmienne i przez caly czas działały tak, jak je pierwotnie zaprogramowano. W zamyśle Vitalika sieć Ethereum miała stać się nie tylko rejestrem zapisującym transakcje kryptowalutowe, ale także „światowym komputerem” - platforma pozwalająca na tworzenie rozproszonych aplikacji korzystajacych $z[\ldots]$ technologii blockchain, na której bytyby osadzone. Ostatecznie sieć Ethereum została uruchomiona 30 lipca 2015 r. i [...] jest rozwijana jako drugi co do wielkości, otwarty blockchain, którego obszar zastosowań wyszedł daleko poza transfer kryptowalut ${ }^{20}$.

${ }^{16}$ K. Helms, Europol Discusses Bitcoin as Store of Value and Payment Method With the Industry, Bitcoin.com, 6 lipca 2017 r., https://news.bitcoin.com/europol-bitcoin-store-of-value-legitimate-payment-method [dostęp: 9 grudnia 2018 r.].

${ }^{17}$ Krypowaluty „kopie się” (potocznie), choć specjaliści twierdzą, że „frezuje się”, czyli „szlifuje się cyfrowe bloki, aby do siebie pasowały” - jest to „dowód pracy”. „Górnicy”/„szlifierzy" rozwiązują zagadki działające na plikach o rozmiarze np. $1 \mathrm{MB}$, uzyskując z tego tytułu wynagrodzenie w kryptowalucie.

${ }_{18}$ R. Pietras, Jak działa Bitcoin, op. cit.

19 Http://www.ioi2012.org/competition/results-2/ [dostęp: 28 listopada 2018 r.].

${ }^{20}$ B. Klinger, J. Szczepański, Blockchain - historia, op. cit., s. 13-14. 
Zarówno bitcoin, jak i ethereum są pierwowzorami dla innych rozwiązań, które intensywnie się rozwijają i ewoluują, jak np. bitcoin cash, bitcoin gold, litecoin, dogecoin, monero, zcash (tabela 1). Poznanie podstawowych mechanizmów działania pierwszych dwóch sieci pozwala zrozumieć pozostałe rozwiązania określane jako technologie blockchain. Część najbardziej postępowych banków centralnych podjęło prace badawcze, a niektóre $\mathrm{z}$ nich i wdrożeniowe, dla tworzenia „narodowych” kryptowalut (np. w Dubaju) ${ }^{21}$.

Tabela 1. Wybrane informacje dotyczące przykładowych sześciu kryptowalut

\begin{tabular}{|c|c|c|c|c|c|c|}
\hline & $\begin{array}{l}\text { Bitcoin } \\
\text { (BTC) }\end{array}$ & $\begin{array}{l}\text { Ethereum } \\
\text { (ETH) }\end{array}$ & $\begin{array}{l}\text { Litecoin } \\
\text { (LTC) }\end{array}$ & $\begin{array}{c}\text { Dogecoin } \\
\text { (DOGE) }\end{array}$ & $\begin{array}{l}\text { Monero } \\
\text { (XMR) }\end{array}$ & $\begin{array}{l}\text { Zcash } \\
\text { (ZEC) }\end{array}$ \\
\hline $\begin{array}{l}\text { Moment powstania } \\
\text { pierwszego bloku }\end{array}$ &  & 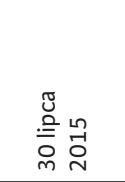 & 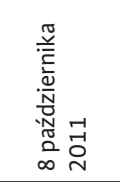 & $\begin{array}{l}\frac{\pi}{\frac{\pi}{c}} \\
\frac{0}{3} \\
\text { 늠 } \\
\infty \\
\infty\end{array}$ & 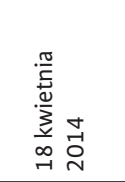 & 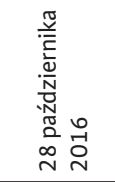 \\
\hline $\begin{array}{l}\text { Rozmiar łańcucha bloków } \\
\text { (w GB) }\end{array}$ & 228,81 & 667,10 & 21,05 & 32,41 & 63,75 & 20,37 \\
\hline Czas tworzenia bloku & $10 \min 17 \mathrm{~s}$ & $14 \min 7 s$ & $2 \min 35 s$ & $1 \mathrm{~min} 2 \mathrm{~s}$ & $1 \mathrm{~min} 56 \mathrm{~s}$ & $2 \min 32 s$ \\
\hline $\begin{array}{l}\text { Cena na } 19 \text { grudnia } 2018 \mathrm{r} \text {. } \\
\text { (w dolarach US) }\end{array}$ & 3801,91 & 104,03 & 30,77 & 0,0026 & 48,75 & 60,66 \\
\hline $\begin{array}{l}\text { Kapitalizacja rynku } \\
\text { (w tys. dolarów US) }\end{array}$ & 66270,16 & 10807,28 & 1835,15 & 309,87 & 813,98 & 330,55 \\
\hline $\begin{array}{l}\text { Średnia liczba transakcji } \\
\text { na godzinę }\end{array}$ & 11802 & 23309 & 1042 & 1382 & 187 & 134 \\
\hline
\end{tabular}

Źródło: https://bitinfocharts.com/ [dostęp: 19 grudnia 2018 r.].

Istnieją dwa sposoby pozyskiwania kryptowaluty: wydobycie i nabycie. „Wydobywanie”22 wymaga przeprowadzenia skomplikowanych obliczeń z wykorzystaniem kart graficznych lub wyspecjalizowanego sprzętu. Innym niż wydobywanie (i w praktyce najczęstszym) sposobem pozyskiwania kryptowalut jest ich zakup na rynku wtórnym. W przypadku chęci nabycia wymaga to założenia „internetowego portfela” (dostępny online), w którym będą przechowywane prywatne klucze szyfrujące i pieniądze, lub zarejestrowania się u zewnętrznego operatora. Możliwe jest także stosowanie papierowych portfeli, w których $\mathrm{np}$. BTC są nadrukowane w postaci kodów dwuwymiarowych (QR) lub użycie sprzętowych portfeli elektronicznych (np. w postaci nośników USB). Przy tym wyróżnia się cztery metody zakupu kryptowalut ${ }^{23}$ :

- od innego użytkownika (podstawowa i jedna z pierwszych) - metoda ta powoduje problemy w postaci: trudności w znalezieniu osoby chętnej na

${ }^{21}$ D.J. Galeon, Dubai just got its first official cryptocurrency, „Business Insider” z 2 października 2017 r., http://www.businessinsider.com/dubai-official-cryptocurrency-blockchain-emcash-2017-10?IR=T. [dostęp: 8 grudnia 2018 r.].

${ }^{22}$ Https://pl.farnell.com/cryptocurrency-ecosystem [dostęp: 11 grudnia 2018 r.].

${ }^{23}$ Ibidem, s. 34-35. 
wymianę kryptowaluty; niepewności otrzymania jej po dokonaniu zapłaty; powstały strony internetowe, które świadczą usługi w pośrednictwie w wymianie kryptowalut na pieniądze (najczęściej w formie gotówki); jednak zaleca się ostrożność w korzystaniu z nich ze względu na ewentualne ryzyko oszustwa i braku pewności, co do legalności pochodzenia środków (weryfikacja tożsamości nie jest często przeprowadzana, a stosowane przez sprzedawców marże są wysokie - nawet 10\%); sytuację te poprawiają niektóre banki akceptujące depozyty gotówkowe, za które dostarczają bitcoiny już kilka godzin po dokonaniu transakcji,

- w kantorach kryptowalutowych, tj. od podmiotu specjalizującego się w wymianie walut; kantory oferują szybki zakup walut cyfrowych, mają niekiedy biura, lecz często doliczają marżę uwzględniającą koszty prowadzenia lokalu i zatrudnienia pracowników; można liczyć w nich na bezpłatne doradztwo, edukację w zakresie kryptowalut; niekiedy weryfikacja tożsamości nie jest tak rygorystyczna jak w przypadku większości giełd kryptowalutowych,

- wykorzystanie bankomatów bitcoinowych (w Polsce tzw. bitomaty) w niektórych krajach pojawiły się bankomaty (wpłatomaty), które akceptują fizyczne pieniądze, a następnie skanują kod QR portfela użytkownika i przelewają adekwatną liczbę kryptowalut na jego konto; w zależności od udziału operacji gotówkowych w społeczeństwie istnieje rozbudowana ich sieć (np. w USA w 2017 r. było ich ponad 1000) lub bardzo ograniczona (np. w Polsce w 2017 r. było ich kilka) i może dotyczyć bitcoin, dash,

- na giełdach kryptowalut, na których ceny są ustalane przez wolny rynek (wykres 1). Stworzono już ponad 1000 kryptowalut, a ich liczba nadal rośnie. Występują więc giełdy umożliwiające wymianę pieniądza tradycyjnego na kryptowaluty oraz takie, które tylko dają możliwość wymiany jednej kryptowaluty na inną; najpopularniejszymi giełdami na świecie są założone w USA giełda Bitfinex, Bitstamp, Poloniex oraz Kraken ${ }^{24}$ (największymi giełdami działającymi na polskim rynku były: BitBay, BitMarket, BitMarket24, a także serwis InPay) ${ }^{25}$. Zalecane jest korzystanie z tych giełd, które mają renomę oraz funkcjonują od dłuższego czasu, aby uniknąć ewentualnych problemów prawnych i próby oszustwa ze strony giełdy. Nie gwarantuje to jednak $100 \%$ bezpieczeństwa. Pokazuje

${ }^{24}$ R. Bielecki, Analiza wybranych giełd kryptowalutowych na świecie, http://www.lazarski. $\mathrm{pl} / \mathrm{pl} /$ wydzialy-i-jednostki/instytuty/wydzial-ekonomii-i-zarzadzania/centrum-technologii-blockchain/analiza-wybranych-gield-kryptowalutowych-na-swiecie [dostęp: 24 listopada 2018 r.].

25 A. Adamowicz, M. Zacharski, Analiza wybranych giełd kryptowalutowych w Polsce, http://www.lazarski.pl/pl/wydzialy-i-jednostki/instytuty/wydzial-ekonomii-i-zarzadzania/ centrum-technologii-blockchain/analiza-wybranych-gield-kryptowalutowych-w-polsce [dostęp: 15 grudnia 2018 r.]. 
to przypadek funkcjonującej od 2012 r. polskiej giełdy kryptowalutowej Bitcurex, która pod koniec 2016 r. nagle, bez ostrzeżenia, zawiesiła swoją działalność (miała certyfikat compliance). W efekcie poszkodowani zostali użytkownicy tej giełdy, a niektórzy stracili kwoty nawet kilkudziesięciu tysięcy złotych. W skali całego rynku nie była to duża strata, ponieważ suma zdeponowanych na niej środków wynosiła ok. 3-5\% wszystkich środków (kryptowalutowych i tradycyjnych) utrzymywanych łącznie na polskich giełdach ${ }^{26}$. Właściciele Bitcurexa poinformowali, że utracili pieniądze w związku $\mathrm{z}$ atakiem hakerskim na konta giełdy, ale podejrzewa się defraudację, ponieważ użytkownicy stracili również polskie złote, które były zdeponowane na rachunkach bankowych.

\section{Sytuacja na rynku kryptowalut}

Liczba miejsc, w których np. bitcoin jako waluta mogą być wydawane, rośnie. Dotyczy to głównie punktów detalicznych (większych i mniejszych), a rosnąca akceptacja tej formy zauważalna jest $w$ wielu miejscach na świecie. Na przykład 20 września 2013 r. bitcoin został uznany za pełnoprawny pieniądz prywatny w Niemczech, w Szwajcarii można nim opłacać podatki lokalne, a od kwietnia 2017 r. urząd regulacyjny w Japonii zatwierdził go jako legalną metodę płatniczą w kraju ze wszystkimi tego konsekwencjami. Zakłada się, że wraz ze wzrostem popularności walut cyfrowych gospodarstwa domowe zmniejszą ilość przetrzymywanej przez siebie gotówki, ponieważ rozpoczną dokonywanie niektórych płatności za ich pomocą. Na tym tle we wrześniu 2017 r. Chiny zdelegalizowały oferty crowdfundingowe oparte na blockchainie, tzw. ICO (Initial Coin Offerings), i ogłosiły zamiar wprowadzenia zakazu wymiany kryptowalut ${ }^{27}$.

Wskazuje się, że rynek kryptowalut jest rynkiem podatnym na manipulacje finansowe i spekulacyjne. Można podać przykład aktywności Bitfinexu (wspomnianej już jednej z największych giełd kryptowalut na świecie). Na podstawie analizy transakcji tej giełdy odkryto pewne stałe wzorce sugerujące podbijanie cen, podczas gdy na innych giełdach cena spadała. Użyto do tego celu innej kryptowaluty - tethera, która została stworzona i sprzedawana przez właścicieli Bitfinexu ${ }^{28}$. Wysoka zmienność cen kryptowalut powoduje, że podatne są one na manipulacje (np. $z$ bitcoinem są powiązane inne cyfrowe waluty, jak bitcoin cash, ethereum, litecoin), więc problem jednej waluty wpływa na pozostałe. $\mathrm{Na}$

${ }^{26}$ K. Piech, O upadkach giełd bitcoinowych - ciag dalszy, http://piech.blog. pl/2016/10/25/o-upadkach-gield-bitcoinowych-ciag-dalszy [dostęp: 24 listopada 2018 r.].

27 D. Heller, The Implications of Digital Currencies for Monetary Policy, „Monetary Dialogue" maj 2017, http://www.europarl.europa.eu/cmsdata/118907/PIIE_FINAL\%20upload. pdf, s. 9 [dostęp: 9 grudnia 2018 r.].

${ }_{28} \mathrm{Https} / /$ www.money.pl/gielda/wiadomosci/artykul/bitcoin-manipulacje-bitfinex-kryptowaluty, 12,0,2408972.html [dostęp: 10 grudnia 2018 r.]. 
przykładzie bitcoina widoczne są istotne zmiany wartości tej wirtualnej waluty na kilku giełdach przy zachowaniu podobnych tendencji na rynku (wykres 1):

- 5 października 2009 r. ustalono kurs wymiany na podstawie kosztu wydobycia 1 dolara US $=1309$ BTC $^{29}$,

- 9 lutego 2011 r. po raz pierwszy w historii $1 \mathrm{BTC}=1$ dolar US,

- 2 czerwca 2011 r. -1 BTC = 10 dolarów US,

- 11 grudnia 2017 r. -1 BTC = 13818,3 dolara US,

- 10 grudnia 2018 r. -1 BTC = 3184,6 dolara US.

Wskazuje się, że mimo cechy, jaką jest homogeniczność, ceny w różnych krajach, a nawet w różnych kantorach wymiany czy na giełdach są zróżnicowane. Umożliwia to przeprowadzanie arbitrażu, czyli kupowania w miejscach, w których waluta ta jest tańsza i sprzedawania w miejscach, w których cena tej waluty jest wyższa (np. cena BTC w Południowej Korei w 2017 r. była wyższa o $35 \%$, a w Indiach wahała się pomiędzy $20-25 \%$ wyżej w porównaniu z ceną w USA, przy czym popyt i podaż miały również swój wpływ na ten wynik ${ }^{30}$. Zdaniem ekspertów powodów zmiany na rynku kryptowalut jest wiele, m.in. aktywność spekulantów, brak jasnych regulacji rynku, powiązanie walut cyfrowych $\mathrm{z}$ „czarną strefą” (pranie brudnych pieniędzy) czy unikanie płacenia podatków ${ }^{31}$.

Obrót kryptowalutami odbywa się elektronicznie, bez udziału systemu bankowego, a bezpośrednio między użytkownikami waluty kryptograficznej. Oznacza to, że transakcja nie powinna być w żaden sposób nadzorowana, więc zakładano początkowo, że nie ma podmiotu, który poinformuje organy skarbowe, jeżeli ktoś będzie chciał sprzedać dużą liczbę jednostek kryptowaluty (jak dzieje się to w Polsce w przypadku transakcji bankowych na kwotę przekraczającą równowartość 15 tys. euro $)^{32}$. Nikt nie powinien też „zablokować" konta, a komornik nie może zająć tych pieniędzy ${ }^{33}$. Jednak istnieją trzy obszary regulacji prawnych, które należy rozważyć: ochrona konsumenta, walka z praniem brudnych pieniędzy oraz opodatkowanie. Na przykład w USA wszelkie operacje związane z transferami pieniędzy są regulowane przez instytucję Financial Crimes Enforcement Network (FinCEN), najpierw na poziomie federalnym, a później na poziomie poszczególnych stanów. W marcu 2013 r. FinCEN rozszerzyła zakres swojego działania o giełdy kryptowalut oraz o inne podmioty zajmujące się handlem cyfrowymi walutami ${ }^{34}$.

2922 maja 2010 r. za zakup pizzy zapłacono 10000 BTC.

${ }^{30}$ P. Bajpai, How to buy Bitcoin, 4 grudnia2018 r., https://www.investopedia.com/tech/ how-to-buy-bitcoin/ [dostęp: 10 grudnia 2018 r.].

31 Https://www.money.pl/banki/wiadomosci/artykul/bitcoin-moze-zdrozec-w-przyszlym-roku-pomoga,8,0,2424072.html [dostęp: 15 grudnia 2018 r.].

${ }^{32}$ Art. 8 ustawy z 16 listopada 2000 r. o przeciwdziałaniu praniu pieniędzy oraz finansowaniu terroryzmu, t.j. Dz.U. 2017, poz. 1049, ze zm.

${ }_{33} \mathrm{Https} / / /$ ergokantor.pl/co-to-sa-kryptowaluty.html [dostęp: 12 grudnia 2018 r.].

${ }^{34} \mathrm{Https} / / /$ pl.farnell.com/cryptocurrency-ecosystem [dostęp: 11 grudnia 2018 r.]. 


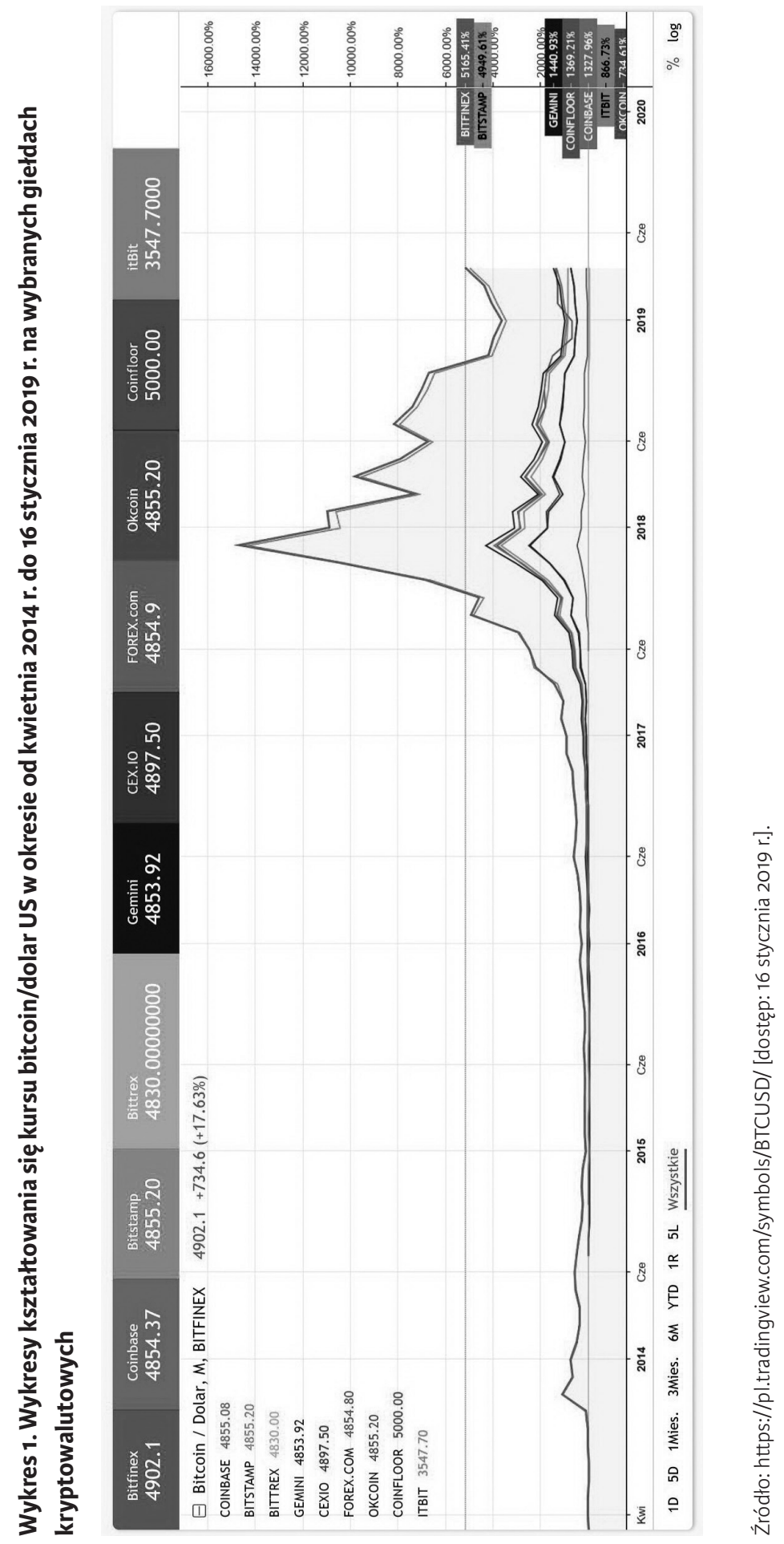


W czerwcu 2015 r. Szwajcaria zdefiniowała bitcoin jako walutę, dlatego obrót nim nie podlega opodatkowaniu VAT w tym kraju. Po wejściu Polski na światowe rynki kryptowalutowe, przez długi czas niejasne były zagadnienia podatkowe związane z obrotem tymi walutami (np. urzędy skarbowe narzuciły stawkę 23\% VAT-u na obrót, podczas gdy na podstawie tego samego prawa unijnego w Wlk. Brytanii stawka wynosiła 0\%). Dopiero po wyroku Europejskiego Trybunału Sprawiedliwości z 22 października 2015 r. w Polsce (od 15 lutego 2016 r.), jak i w całej UE, transakcje wymiany walut konwencjonalnych na BTC korzystaja ze zwolnienia z podatku VAT ${ }^{35}$.

W Polsce od 1 stycznia 2019 r. zmieniły się zasady dotyczące wirtualnych walut. Inwestorzy handlujący kryptowalutami będą wykazywać dochód z kapitałów pieniężnych. Po odliczeniu kosztów zapłacą 19\% podatku od zysków kapitałowych. Rozliczenie strat z poprzednich lat będzie niemożliwe, ponieważ w myśl nowych przepisów zostały one poniesione z innego źródła przychodów z działalności gospodarczej lub prawa majątkowego ${ }^{36}$ (dotychczas obrót był opodatkowany podatkiem dochodowym).

Status prawny np. bitcoina różni się między poszczególnymi państwami i w wielu $\mathrm{z}$ nich nie jest jeszcze zdefiniowany albo się zmienia. $\mathrm{O}$ ile większość państw nie uznaje bitcoina za walutę nielegalną, jego status jako pieniądza (lub towaru) różni się ze względu na odmienne konsekwencje, wynikające z konkretnych uregulowań ${ }^{37}$. Sugeruje się, że dobrym pomysłem byłoby stworzenie oddzielnych regulacji dla kryptowalut, a nie wpisywanie ich jako poprawki do dyrektywy MIFID2 ${ }^{38}$ (październik 2018 r.). Dyrektywa ta ma chronić inwestorów przed ryzykownymi inwestycjami w instrumenty finansowe. Uzasadniano, że wirtualne waluty są przez inwestorów traktowane jako substytuty instrumentów finansowych (uznanie ich za takie instrumenty spowodowałoby, że obrót nimi byłby trudniejszy, bardziej czasochłonny i droższy) $)^{39}$. Bańka spekulacyjna na walutach wirtualnych (w tym na BTC) spowodowała potrzebę uregulowania tego rynku. Osoby, które kupiły BTC w celach inwestycyjnych, straciły w 2018 r. nawet kilkaset tysięcy złotych (w skali świata szacuje się, że z rynku „zniknęło” ponad 600 mld dolarów $\mathrm{US}^{40}$ ).

Na rynku pojawia się wiele podmiotów informujących o giełdach kryptowalut, np. Coin Market Cap. Uważa się bowiem, że jeśli danej waluty cyfrowej nie

${ }^{35}$ Podstawy korzystania, op. cit., s. 31-32.

36 Https://www.money.pl/gospodarka/wiadomosci/artykul/bitcoin-podatki,253,0, 2423037.html [dostęp: 3 grudnia 2018 r.].

37 Https://pl.farnell.com/cryptocurrency-ecosystem [dostęp: 11 grudnia 2018 r.].

$38 \mathrm{Https} / /$ www.money.pl/gospodarka/unia-europejska/wiadomosci/artykul/ue-chce-regulowac-bitcoiny-kontrowersyjna,8,0,2417672.html [dostęp: 10 grudnia 2018 r.].

39 Ibidem.

${ }^{40} \mathrm{Https} / /$ www.money.pl/pieniadze/wiadomosci/artykul/waluty-kryptowaluty-bitcoin-spadki-gielda-btc,206,0,2421710.html [dostęp: 19 listopada 2018 r.]. 
ma w spisie na stronie internetowej uznanego podmiotu, to oznacza, że jest to piramida finansowa podszywająca się pod kryptowalutę albo nie została w nim jeszcze umieszczona, lub jej obroty/kapitalizacja są zbyt niskie, by zyskały uwagę redaktorów serwisu.

\section{Zalety i wady kryptowalut a perspektywy rozwoju ich rynku}

Eksperci nie są zgodni, czym są kryptowaluty, a tym bardziej jak potoczy się ich dalszy los. Kierunków jest kilka, co wynika z ich zalet i wad, ale ze względu na objętość opracowania zostaną wskazane tylko wybrane. Do zalet kryptowalut niewątpliwie należą:

- możliwość przechowywania ich na komputerze czy w smartfonowej aplikacji w tzw. portfelu, do którego dostęp ma tylko osoba znająca klucz dostępu,

- zróżnicowanie kryptowalut (ponad 1000) i ich dostępność - większość pośredników (w tym giełdy) umożliwia zarówno zakup, jak i sprzedaż wybranych kryptowalut, a także wymienianie ich na gotówkę czy na inne kryptowaluty,

- akceptowanie przez niektóre banki i kraje możliwości dokonywania transakcji zakupu rzeczywistych produktów czy usług za pomocą wybranych kryptowalut, których pozycja jest „ugruntowana” na rynku,

- inwestowanie na rynku pieniędzy w kryptowaluty - część ekspertów uważa, że są zbliżone do akcji spółek, które mają pewną wartość fundamentalną i przekonują, że 1 BTC może w ciągu najbliższych lat osiągnąć wartość 1 mln dolarów US (rosnąca popularność przy limitowanej podaży - górny limit tej waluty został ustanowiony w protokole na $21 \mathrm{mln}$ dolarów US do $2131 \mathrm{r}^{41}$ - sugerują, że wzrost jego wartości jeszcze się nie zakończył),

- technologia, na której są oparte, generuje niższe koszty jej użytkowania, w porównaniu z systemami centralnymi, i większe bezpieczeństwo, w tym odporność na ingerencję obcych służb czy międzynarodowych grup hakerskich ${ }^{42}$ (stanowi otwarty i niedrogi sposób dla banków i innych organizacji na przekazywanie sobie środków - przez co usługi finansowe mogą być bardziej dostępne). Żaden dostępny raport nie wskazał dotąd przypadku wykorzystania kryptowalut przez terrorystów, a dla przestępców są one na ogół zbyt trudne lub zbyt mało anonimowe (co potwierdził raport $\mathrm{UE})^{43}$,

${ }^{41}$ R. Pietras, Jak działa Bitcoin, op. cit.

42 Podstawy korzystania, op. cit., s. 14.

43 Ibidem, s. 9-10; http://europeanmemoranda.cabinetoffice.gov.uk/files/2017/07/1097717-ADD-2.pdf [dostęp: 8 grudnia 2018 r.]. 
- brak nadzoru nad tym pieniądzem przez jedną centralną instytucję (w odróżnieniu od pieniądza tradycyjnego), niemożność wydania go dwukrotnie i trudność w pozyskaniu.

Do wad kryptowalut należy niewątpliwie to, że:

- ich wartość jest niestabilna, ulega wahaniom na skutek: aktywności spekulantów, braku jasnych regulacji rynku, powiązania walut cyfrowych z procederem „prania brudnych pieniędzy” czy unikania płacenia podatków; część ekspertów traktuje je jak prawo do własności intelektualnej, którego siła nabywcza będzie systematycznie spadać,

- powodują pojawianie się manipulacji finansowych czy oszustw finansowych lub technicznych, które prowadzą do strat wśród inwestorów (np. na początku 2014 r. Mt.Gox była największą giełdą bitcoinową na świecie, przeprowadzającą ponad 70\% wszystkich światowych transakcji tą walutą; do końca lutego stała się bankrutem; ofiary zmasowanego ataku straciły ok. 740000 BTC (6\% wszystkich istniejących wówczas BTC) o wartości 460 mln euro (i ponad 3 mld dolarów US w cenach z października $2017 \mathrm{r}$. $)^{44}$,

- inwestowanie w nie i w ICO jest bardzo ryzykowne ${ }^{45}$; przestrzega się, że: zbyt pochopne wchodzenie wświat kryptowalut może wiazać się z zagrożeniami. W szczególności, spekulowanie zawsze jest obarczone ryzykiem ${ }^{46}$ np. górny limit BTC może nieść ryzyko inwestycyjne, podobnie jak zakup akcji dużej spółki w długim horyzoncie inwestycyjnym ${ }^{47}$.

Kryptowaluty, oprócz aspektu technicznego, mają więc i aspekt ekonomiczny, który wiąże się z pytaniem: czy mają wartość fundamentalną? Jeśli tak, to ich cena może powoli, lecz systematycznie rosnąć ze względu na ograniczoną podaż. Jeśli zaś jej nie mają, to mogą być wyłącznie bańkami spekulacyjnymi ${ }^{48}$. Obawy o ryzyko inwestycyjne są rozwiewane przez stwierdzenia, że rynek ten funkcjonuje już na tyle długo, że wiadomo, jakie są to ryzyka i jak je ograniczyć. Powstają inicjatywy takie jak tworzenie kontraktów terminowych na bitcoin, oferowane na giełdzie, które będą rozliczane w BTC, nie w dolarach US. Ta kryptowaluta będzie skupowana z rynku celem przechowywania jej przez platformę Bakkt aż do wygaśnięcia kontraktu (co może być powodem do wzrostów cen

${ }^{44}$ Https://blockonomi.com/mt-gox-hack/ [dostęp: 15 grudnia 2018 r.].

45 P. Bajpai, How to buy Bitcoin, https://www.investopedia.com/tech/how-to-buy-bitcoin/ z 4 grudnia 2018 r. [dostęp: 10 grudnia 2018 r.].

${ }^{46}$ Podstawy korzystania, op. cit., s. 6; Komunikat Narodowego Banku Polskiego i Komisji Nadzoru Finansowego w sprawie „walut” wirtualnych, NBP, 7 lipca 2017 r., http://www.nbp. pl/home.aspx?f=/aktualnosci/wiadomosci_2017/ww-pl.html [dostęp: 14 grudnia 2018 r.].

${ }_{47}$ R. Pietras, Jak działa Bitcoin, op. cit.

48 Ibidem. 
BTC w 2019 r.). Są także chętni na akcje na blockchainie, np. Neufund zebrał w pierwszej ofercie $3 \mathrm{mln}$ euro (to tzw. Security Token Offering, STO, który jest udoskonalonym modelem tradycyjnych instrumentów finansowych $)^{49}$.

W mediach wskazuje się na wątpliwą albo świetlaną przyszłość kryptowalut. Część osób używa ich do nabywania rzeczy, choć Overstock.com (największy detaliczny serwis internetowy akceptujący BTC) informował, że BTC odpowiadała za mniej niż 0,1\% transakcji sprzedaży. Część inwestorów liczy, że: cechy Bitcoina pozwalają mu swobodnie działać i rosnąć w obrębie coraz większej strefy aktywności. Oznacza to, że nieuniknione jest, że zacznie on w końcu zastępować środki płatnicze o gorszych cechach. Bitcoin będzie rósł jak hydra, której nowe głowy wyrastaja w każdym kraju i w każdej społeczności. Pożre dotychczasowy system finansowy, który był nierozerwalnie związany $z$ watpliwym $w$ swej stuszności pieniądzem fiducjarnym i pozostawi otwarty, rozszerzający się, nowy system finansowy. To do was wszystkich należy zadanie, by okiełznać i rozwijać ten nowy rynek ${ }^{50}$. Nie można więc wykluczyć, że w przyszłości kryptowaluty wyprą zwykły, słabiej zabezpieczony bankowy pieniądz elektroniczny. Będzie on „spełnieniem marzeń" urzędów skarbowych, ponieważ wszystkie transakcje na blockchainie mogą być dostępne (zebrane w jednej bazie danych), co umożliwi prześledzenie ich przepływów ${ }^{51}$.

We wprowadzeniu kryptowalut upatruje się korzyści dla społeczeństw i dla gospodarki, licząc, że np. spadną koszty transakcyjne, zmniejszy się odsetek oszustw i fałszerstw czy skala korupcji, zwiększy się zaś odsetek transakcji międzynarodowych, co przyspieszy wzrost gospodarczy ${ }^{52}$. Niektóre kraje, np. Gruzja i Rosja, otwarcie popierają „kopanie” kryptowalut, tworząc korzystne warunki dla jego rozwoju (m.in. ułatwienia podatkowe dla firm kryptowalutowych), ale są i takie, które są zdecydowanie przeciwne (np. Wenezuela, Tajlandia) ${ }^{53}$.

Innym kierunkiem jest przykład Crypto Valley Zug, czyli miasteczka, w którym lokalny polityk D. Müller zainicjował projekt, aby stało się ono siedzibą wiodących w branży przedsiębiorstw blockchainowych (np. Ethereum, polski projekt Golem). Powstają pytania o możliwości tworzenia „dolin blockchainowych" w Polsce (uwzględniając poziom intelektualny polskich informatyków

${ }^{49}$ Https://www.money.pl/banki/wiadomosci/artykul/bitcoin-moze-zdrozec-w-przyszlym-roku-pomoga,8,0,2424072.html [dostęp: 15 grudnia 2018 r.].

${ }^{50} \mathrm{Https} / /$ pl.farnell.com/cryptocurrency-ecosystem [dostęp: 11 grudnia 2018 r.].

${ }^{51}$ Podstawy korzystania, op. cit., s. 11.

52 T. Ward, China Becomes First Country in the World to Test a National Cryptocurrency, Futurism, 23 czerwca 2017 r., https://futurism.com/china-becomes-first-countrchina-becomes-first-country-in-the-world-to-test-a-national-cryptocurrencyy-to-test-national-cryptocurrency [dostęp: 8 grudnia 2018 r.]; Podstawy korzystania, op. cit., s. 11.

${ }_{53}$ H. Amos, Russia Is Becoming a Cryptocurrency Haven, The Moscow Times, 9 lipca 2017 r., https://themoscowtimes.com/articles/russia-is-becoming-a-cryptocurrency-haven-58175 [dostęp: 7 grudnia 2018 r.]. 
czy niewielkie jeszcze nakłady kapitałowe). Pomocne byłyby regulacje prawne, a nawet deregulacje (np. $\mathrm{w}$ formie dedykowanego środowiska regulacyjnego do testowania rozwiązań $)^{54}$.

Warto również wspomnieć o pseudokryptowalutach (tj. projektach „kryptowalutopodobnych”), czyli takich, które jedynie podszywają się pod kryptowaluty, wykorzystując ich rosnącą popularność (i ceny), ale w rzeczywistości nie spełniają ich prawdziwych cech, takich jak: kod otwartoźródłowy, dostępny i weryfikowalny opis projektu, transparentność transakcji oraz brak konieczności istnienia zaufanych trzecich stron odpowiadających za działanie kryptowaluty. Są one często piramidami finansowymi ${ }^{55}$.

Jest jeszcze jeden kierunek, a mianowicie delegalizacja kryptowalut. Należy jednak zwrócić uwagę, że delegalizacja produktów z wysokim popytem zwiększa ich wartość na tzw. czarnym rynku i tym samym napędza nielegalny handel. Jest to kontrargument dla pozornie największego zagrożenia dla kryptowalut.

\section{Podsumowanie}

Od wprowadzenia technologii łańcucha bloków i bitcoina minęło dziesięć lat. Zastosowane technologie wywarły silny wpływ na ludzi, którzy zdecydowali się z nich korzystać i je rozwijać. Idea wirtualnego, nienadzorowanego przez jedną instytucję pieniądza światowego (w odróżnieniu od pieniądza tradycyjnego), którego nie można wydać dwukrotnie w transakcjach i w łatwy sposób pozyskać (bez pośredników w postaci kantorów czy giełd), została wprowadzona w życie. Ze względu na swoje zalety i wady ma zwolenników i przeciwników. Zmienność wartości niektórych kryptowalut przyczyniła się do inwestowania w nie przez ludzi, wśród których część osiągnęła wysokie zyski lub poniosła straty ${ }^{56}$. Stąd przyszłość kryptowalut jest niepewna, gdyż jedni przewidują ich szybki rozwój, inni wieszczą nieunikniony upadek (w wyniku „znikania” kryptowalut czy giełd handlujących nimi, a także powstawania „nieprawdziwych” kryptowalut, co budzi zrozumiały niepokój). Jednakże to sama technologia blockchainu jest obiecująca i może zostać użyta w wielu aplikacjach (nie tylko związanych z kryptowalutami), na co zresztą znaleźć już można przykłady w instytucjach finansowych (banki, zakłady ubezpieczeń, jako tzw. fintech).

\section{Bibliografia}

Adamowicz A., Zacharski M., Analiza wybranych giełd kryptowalutowych w Polsce, http:// www.lazarski.pl/pl/wydzialy-i-jednostki/instytuty/wydzial-ekonomii-i-zarzadzania/

\footnotetext{
${ }^{54}$ Podstawy korzystania, op. cit., s. 13.

${ }_{55}$ Ibidem, s. 12.

${ }^{56}$ Https://pl.farnell.com/cryptocurrency-ecosystem [dostęp: 11 grudnia 2018 r.].
} 
centrum-technologii-blockchain/analiza-wybranych-gield-kryptowalutowych-w-polsce.

Amos H., Russia Is Becoming a Cryptocurrency Haven, „The Moscow Times” z 9 lipca 2017 r., https://themoscowtimes.com/articles/russia-is-becoming-a-cryptocurrency-haven-58175.

Bitcoin: A peer-to-peer electronic cash system, www.bitcoin.org/bitcoin.pdf.

Bielecki R., Analiza wybranych giełd kryptowalutowych na świecie, Uczelnia Łazarskiego, http://www.lazarski.pl/pl/wydzialy-i-jednostki/instytuty/wydzial-ekonomii-i-zarzadzania/centrum-technologii-blockchain/analiza-wybranych-gield-kryptowalutowych-na-swiecie.

Blockchain, a catalyst for new approaches in insurance, PWC, https://www.pwc.com/gx/ en/insurance/assets/blockchain-a-catalyst.pdf.

Galeon D.J., Dubai just got its first official cryptocurrency, „Business Insider” z 2 października 2017 r., http://www.businessinsider.com/dubai-official-cryptocurrency-blockchain-emcash-2017-10?IR=Thttps://pl.farnell.com/cryptocurrency-ecosystem.

Heller D., The Implications of Digital Currencies for Monetary Policy, „Monetary Dialogue" z maja 2017 r., http://www.europarl.europa.eu/cmsdata/118907/PIIE_ FINAL\%20upload.pdf.

Helms K., Europol Discusses Bitcoin as Store of Value and Payment Method With the Industry, „Bitcoin.com” 6 lipca 2017 r., https://news.bitcoin.com/europol-bitcoin-store-of-value-legitimate-payment-method.

Homa D., Sekrety Bitcoina i innych kryptowalut, Helion, Gliwice 2015.

Klinger B., Szczepański J., Blockchain - historia, cechy i główne obszary zastosowań, „Człowiek w Cyperprzestrzeni” 2017, nr 1.

Komunikat Narodowego Banku Polskiego i Komisji Nadzoru Finansowego w sprawie „walut" wirtualnych, NBP, 7 lipca 2017 r., http://www.nbp.pl/home.aspx?f=/aktualnosci/ wiadomosci_2017/ww-pl.html.

Narayanan A. i in., Bitcoin and Cryptocurrency Technologies, Draft, 9 lutego 2016 r., https://lopp.net/pdf/princeton_bitcoin_book.pdf.

Piech K., O upadkach giełd bitcoinowych - ciag dalszy, http://piech.blog.pl/2016/10/25/o-upadkach-gield-bitcoinowych-ciag-dalszy.

Pietras R., Jak działa Bitcoin, „Chip” z 12 marca 2018 r.

Podstawy korzystania $z$ walut cyfrowych, red. K. Piech, Instytut Wiedzy i Innowacji, Warszawa 2017.

Ward T., China Becomes First Country in the World to Test a National Cryptocurrency, „Futurism” z 23 czerwca 2017 r., https://futurism.com/china-becomes-first-countrchina-becomes-first-country-in-the-world-to-test-a-national-cryptocurrencyy-to-test-national-cryptocurrency.

Ustawa z 16 listopada 2000 r. o przeciwdziałaniu praniu pieniędzy oraz finansowaniu terroryzmu, t.j. Dz.U. 2017, poz. 1049, ze zm. 
Https://blockonomi.com/mt-gox-hack/.

Https://ergokantor.pl/co-to-sa-kryptowaluty.html.

Http://europeanmemoranda.cabinetoffice.gov.uk/files/2017/07/10977-17-ADD-2.pdf. Https://gieldykryptowalut.pl/wiadomosci/krotka-historia-upadlych-polskich-gield-kryptowalut/.

Https://lopp.net/pdf/princeton_bitcoin_book.pdf.

Https://poradnikprzedsiebiorcy.pl/-peer-to-peer-definicja-historia-powstania-i-wplyw-

-na-rozwoj-internetu-cz-.

Https://www.money.pl.

Http://www.nbp.pl.

Http://www.ioi2012.org/competition/results-2/. 